\title{
25. STRONTIUM ISOTOPE STRATIGRAPHY OF THE PLIOCENE-PLEISTOCENE "DEEP-SEA TYPE SECTION" AT ODP HOLE 653A ${ }^{1}$
}

\author{
Judith A. McKenzie, ${ }^{2}$ Sarah C. Palmer, ${ }^{3}$ and Paul A. Mueller ${ }^{3}$
}

\begin{abstract}
Strontium isotopic determinations were made on samples from the Pliocene-Pleistocene sequence recovered at ODP Hole 653A, the proposed "deep-sea type section" for the Mediterranean region. Biostratigraphic correlations can be combined with the patterns of variations in the ${ }^{87} \mathrm{Sr} /{ }^{86} \mathrm{Sr}$ values to delineate the following: (1) the earliest Pliocene (MP11 to basal MP12 zones) is distinguished by fluctuations in the ratio, probably related to the unstable paleoceanographic conditions following the Zanclean flooding and initial in-filling of the Mediterranean after the Messinian desiccation, (2) during most of the Pliocene between approximately 4.5 and $2.4 \mathrm{Ma}$ (MP12 to MP15 zones) the ${ }^{87} \mathrm{Sr} /{ }^{86} \mathrm{Sr}$ values remain relatively constant, producing a plateau in the strontium isotope-depth curve for this period, and (3) beginning at approximately $2.4 \mathrm{Ma}$ (across the MP15/MP16 boundary) and continuing into the latest Pleistocene, the ${ }^{87} \mathrm{Sr} /{ }^{86} \mathrm{Sr}$ values increase significantly but show fluctuations that have both positive and negative slopes.

The presence of a plateau in the curve generated for the Mediterranean type section duplicates in greater detail the late Neogene results reported by DePaolo (1986). The virtual lack of change in the ratio between 4.5 and $2.4 \mathrm{Ma}$ essentially eliminates strontium isotopes as a high-resolution correlation method for this period. The fluctuations in the ratio beginning at $2.4 \mathrm{Ma}$ may be a reflection of major climatic changes occurring in the latest Pliocene-Pleistocene. The relationship between glacial-interglacial cycles and seawater ${ }^{87} \mathrm{Sr} /{ }^{86} \mathrm{Sr}$ values suggested by DePaolo (1986) and Capo and DePaolo (1987) is uncertain but should be tested as significant increases and decreases in ${ }^{87} \mathrm{Sr} /{ }^{86} \mathrm{Sr}$ of seawater have apparently occurred since $2.4 \mathrm{Ma}$.
\end{abstract}

\section{INTRODUCTION}

All of the stratotype sections for the Pliocene-Pleistocene chronostratigraphic units are located in Italy. For various reasons, such as incomplete sections, dilution by clastic material, diagenetic overprinting, regional faunal events, etc., these type sections have proven to be less than ideal. In particular, efforts to correlate the Mediterranean Neogene sections with the open ocean using the paleomagnetic time scale have been mostly unsuccessful. A primary drilling objective of ODP Leg 107 was to recover a continuous, pelagic Pliocene-Pleistocene section. Because a nearly complete late Neogene section was previously recovered during deep-sea drilling in the western Tyrrhenian Sea at DSDP Site 132, this site was reoccupied as ODP Site 653 (Fig. 1). It was envisioned that Site 653 would serve as a "deep-sea type section" upon which a complete battery of high-resolution stratigraphic techniques from paleomagnetics to tephra to stable isotope to micropaleontology could be applied and compared to the land and open-ocean sections.

Within the scope of this objective, we proposed to study the strontium-isotope stratigraphy of Hole $653 \mathrm{~A}$. In recent years, the application of strontium isotopes as a stratigraphic tool has shown great promise (Burke et al., 1982; Koepnick et al., 1985; DePaolo and Ingram, 1985; DePaolo, 1986; Elderfield, 1986; and Hess et al., 1986). In particular for the Neogene, DePaolo (1986) has shown that the strontium isotope-age curve for seawater is marked by a general increase in the isotopic ratio toward the present. Variations in the slope suggest that there have been periods of rapid and slow change in the ratio. With the establishment of a "deep-sea type section" in the Mediterranean, it was deemed appropriate that strontium-isotopic measurements be made on sediments from Hole 653A in order to correlate them with the Neogene seawater curve. The initial results presented

\footnotetext{
${ }^{1}$ Kastens, K. A., Mascle, J., et al., 1990. Proc. ODP, Sci. Results, 107: College Station, TX (Ocean Drilling Program).

2 Geological Institute, ETH-Zentrum, 8092 Zürich, Switzerland.

3 Department of Geology, University of Florida, Gainesville, FL 32611.
}

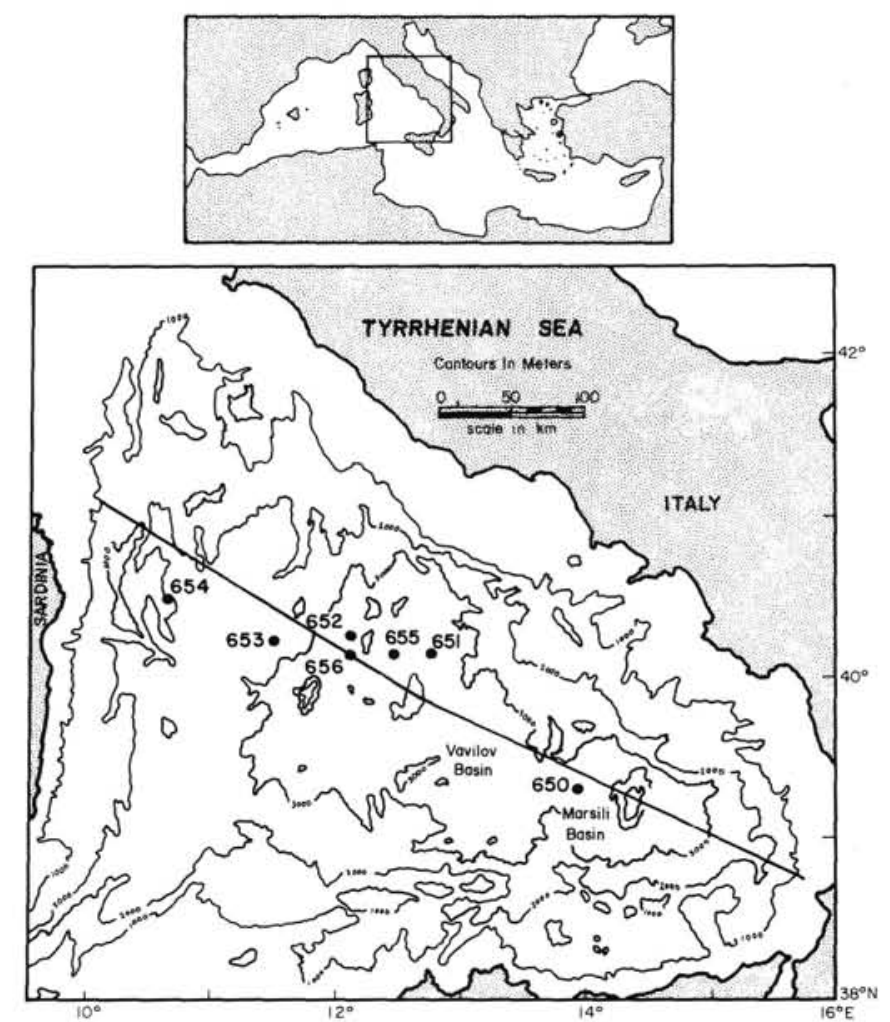

Figure 1. Map of the Tyrrhenian Sea showing the location of ODP Leg 107 , Site 653 , the proposed Neogene "deep-sea type section."

here are those that are relevant to the goal of providing a strontium-isotope stratigraphy for the "deep-sea type section" in conjunction with the other stratigraphic studies. A more detailed analysis of these samples with respect to potential diagenetic alteration and preservation of original values is contained 
in a University of Florida masters thesis currently in preparation by one of us (S.C.P.).

\section{METHODOLOGY}

Planktonic foraminifers were hand-picked from the $>150-\mu \mathrm{m}$ size fraction of 28 previously washed samples selected from regularly spaced intervals throughout the entire Pliocene-Pleistocene section from Hole $653 \mathrm{~A}$; selections were made onboard the JOIDES Resolution. Two samples from the basal Pliocene of Hole 653B were likewise examined. The foraminifers were washed several times in distilled water in an ultrasonic bath followed by decanting and drying. The cleaned foraminifers were dissolved in either $5 \mathrm{~mL}$ of $5 \mathrm{M}$ acetic acid or $5 \mathrm{~mL}$ of $0.25 \mathrm{~N}$ hydrochloric acid. Samples dissolved in acetic acid were converted to chlorides by addition of $20 \mathrm{~mL}$ of $6 \mathrm{~N} \mathrm{HCl}$.

The sample solution was filtered and the volume reduced to $250 \mu \mathrm{L}$ before loading onto a standard Dowex $50 \times 12$ cation exchange column. Samples were eluted in $2 \mathrm{~N} \mathrm{HCl}$ and evaporated to dryness. The $\mathrm{Sr}$ fraction was then loaded as a nitrate on a single oxidized Ta filament. Isotopic ratios were measured on a VG Instruments 354 triple collector mass spectrometer in the dynamic mode with mass fractionation normalized to a ${ }^{86} \mathrm{Sr} /{ }^{88} \mathrm{Sr}$ ratio of 0.1194 . The data are given in Table 1 .

The blank for both chemical procedures was less than $1 \mathrm{ng}$ total strontium. Seventy-six analyses of SRM-987 gave a mean ${ }^{87} \mathrm{Sr} /{ }^{86} \mathrm{Sr}$ of 0.710235 with a two sigma error of $2 \times 10^{-5}$, which is comparable to our intra-run precision and is utilized as our maximum standard error. To minimize the inter-run variability and increase precision, SRM-987 was run at the beginning and end of each set of fourteen samples. Sample ${ }^{87} \mathrm{Sr} /{ }^{86} \mathrm{Sr}$ ratios for each run were then normalized to the long term mean value of SRM-987 based upon the average of the two values obtained for SRM- 987 for that particular run. For 9 of the 28 samples, inter-run standards are not available and are indicated in Table 1.

\section{RESULTS AND CORRELATIONS}

The results of the strontium isotopic analyses are plotted vs. depth at Hole 653A (Fig. 2). The biostratigraphic zonations for

Table 1. Pliocene-Pleistocene strontium-isotope data: ODP Hole 653A.

\begin{tabular}{|c|c|c|}
\hline Sample number & $\begin{array}{l}\text { Depth } \\
\text { (mbsf) }\end{array}$ & ${ }^{87} \mathrm{Sr} /{ }^{86} \mathrm{Sr}^{\mathrm{a}}$ \\
\hline $653 \mathrm{~A}-2 \mathrm{X}-2,95-97 \mathrm{~cm}$ & 5.93 & $0.709129 \pm 13$ \\
\hline $3 X-2,95-97 \mathrm{~cm}$ & 14.80 & $0.709067 \pm 11$ \\
\hline $4 X-2,95-97 \mathrm{~cm}$ & 24.30 & $0.709075 \pm 11$ \\
\hline $5 X-2,95-97 \mathrm{~cm}$ & 33.80 & ${ }^{b} 0.709103 \pm 33$ \\
\hline $6 \mathrm{X}-4,95-97 \mathrm{~cm}$ & 47.70 & ${ }^{b} 0.709069 \pm 14$ \\
\hline $7 X-2,95-97 \mathrm{~cm}$ & 54.10 & ${ }^{b} 0.709041 \pm 14$ \\
\hline $8 \mathrm{X}-2,97-99 \mathrm{~cm}$ & 62.10 & $0.709037 \pm 14$ \\
\hline $9 X-2,95-97 \mathrm{~cm}$ & 71.60 & $0.708981 \pm 14$ \\
\hline $10 X-4,95-97 \mathrm{~cm}$ & 84.20 & $0.708997 \pm 20$ \\
\hline $10 X-6,95-97 \mathrm{~cm}$ & 87.20 & $0.709037 \pm 11$ \\
\hline $11 X-2,95-97 \mathrm{~cm}$ & 90.60 & $0.709007 \pm 14$ \\
\hline $11 X-4,95-97 \mathrm{~cm}$ & 93.60 & $0.709075 \pm 13$ \\
\hline $11 X-6,95-97 \mathrm{~cm}$ & 96.90 & $0.709060 \pm 17$ \\
\hline $13 \mathrm{X}-2,95-97 \mathrm{~cm}$ & 109.30 & $0.708926 \pm 14$ \\
\hline $14 \mathrm{X}-2,95-97 \mathrm{~cm}$ & 118.90 & $0.708928 \pm 14$ \\
\hline $15 X-2,95-97 \mathrm{~cm}$ & 128.20 & $0.708961 \pm 13$ \\
\hline $16 \mathrm{X}-2,95-97 \mathrm{~cm}$ & 136.20 & $0.708896 \pm 17$ \\
\hline $17 X-2,95-97 \mathrm{~cm}$ & 147.20 & $0.708924 \pm 20$ \\
\hline $18 \mathrm{X}-2,93-95 \mathrm{~cm}$ & 156.79 & $0.708897 \pm 14$ \\
\hline $19 X-1,95-97 \mathrm{~cm}$ & 165.70 & $0.708950 \pm 11$ \\
\hline $20 \times-2,95-97 \mathrm{~cm}$ & 175.30 & $0.708921 \pm 16$ \\
\hline $21 X-2,50-52 \mathrm{~cm}$ & 184.75 & $b_{0.708907} \pm 13$ \\
\hline $21 X-4,50-52 \mathrm{~cm}$ & 187.75 & $b_{0.708921 \pm 13}$ \\
\hline $22 \mathrm{X}-2,50-52 \mathrm{~cm}$ & 194.45 & $0.708963 \pm 18$ \\
\hline $22 \times-4,50-52 \mathrm{~cm}$ & 197.45 & ${ }^{b} 0.708929 \pm 14$ \\
\hline $23 \mathrm{X}-2,50-52 \mathrm{~cm}$ & 203.95 & $0.709019 \pm 16$ \\
\hline $23 \mathrm{X}-4,50-52 \mathrm{~cm}$ & 206.95 & $b_{0} 0.708900 \pm 13$ \\
\hline $23 \mathrm{X}-6,125-127 \mathrm{~cm}$ & 210.03 & ${ }^{b} 0.708903 \pm 11$ \\
\hline 653B-23X-2, 96-98 cm & 208.30 & $0.709003 \pm 11$ \\
\hline $23 \times-4,96-98 \mathrm{~cm}$ & 211.30 & ${ }^{b} 0.708953 \pm 13$ \\
\hline
\end{tabular}

a The number following the ${ }^{87} \mathrm{Sr} /{ }^{86} \mathrm{Sr}$ ratio is the analytical uncertainty, referring to last two digits of the ratio.

b Samples without inter-run standards.

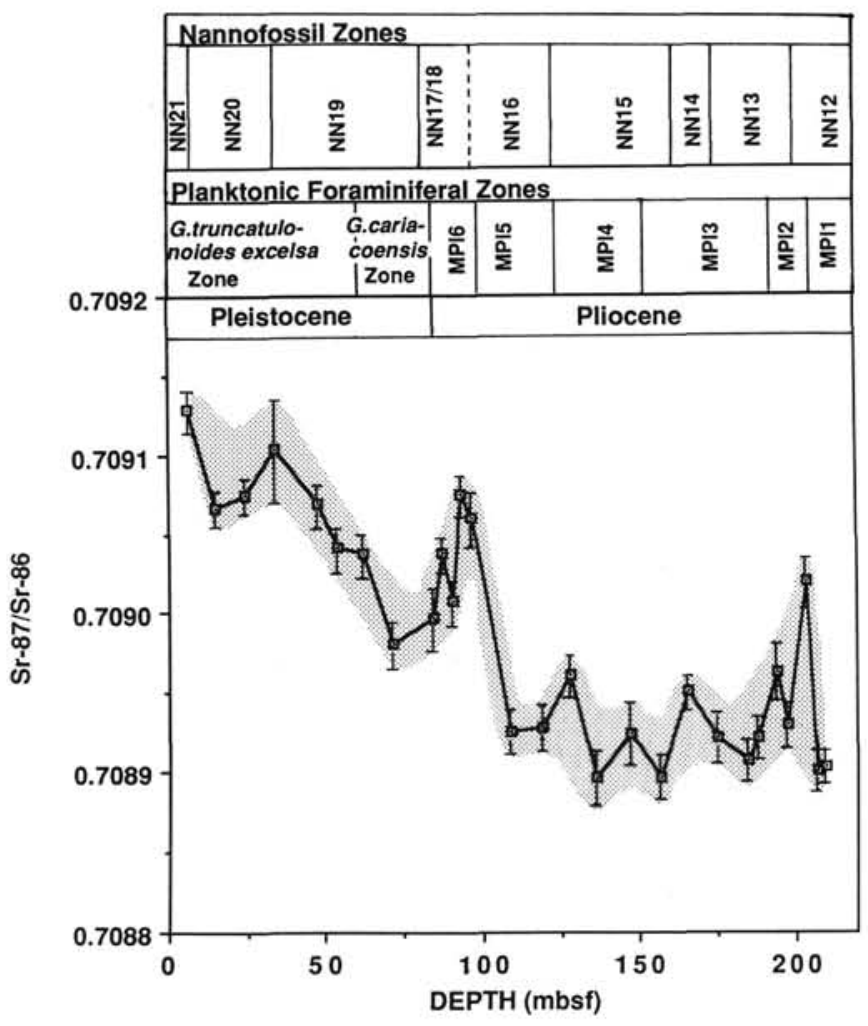

Figure 2. Graph of strontium-isotopic ratios of planktonic foraminifera vs. depth at ODP Hole 653A in the Tyrrhenian Sea. The strontium-isotope variations are correlated with the Pliocene-Pleistocene biostratigraphy (Shipboard Scientific Party, 1987). There is little change in the Srisotopic composition of Tyrrhenian seawater throughout most of the Pliocene, followed by a sharp increase in the ratio at the beginning of the MP16 zone. In general, the Pleistocene is marked by increasing values.

both nannofossils and foraminifers are also shown against depth (Shipboard Scientific Party, 1987). Unfortunately, a secondary overprinting of the magnetic properties of the sediments masked the primary magnetic stratigraphy, eliminating the possibility of direct correlation with the paleomagnetic time scale (Shipboard Scientific Party, 1987). Drilling at Hole 653A did not recover the very earliest Pliocene, but sediments from the MP11 zone, as denoted by an acme of Sphaeroidinellopsis spp., were cored.

Except for the latest Pliocene, the strontium isotopic composition remains notably constant throughout this epoch. The mean ${ }^{87} \mathrm{~S} /{ }^{86} \mathrm{Sr}$ ratio value for 15 samples between the basal Pliocene and $109.3 \mathrm{mbsf}$, within the MP15 zone, is $0.708930 \pm$ $0.000033 ; 0.708923 \pm 0.000022$, if the datum point at 203.95 mbsf is eliminated. Considering this difference, it is assumed that the flat part of the curve begins near $197.45 \mathrm{mbsf}$, which is located below the top of the MP12 zone at approximately 192.5 mbsf and near the beginning of NN13 zone at 196.0 mbsf (Shipboard Scientific Party, 1987). Using the estimated average sedimentation rate of $3.9 \mathrm{~cm} / 1000 \mathrm{yr}$ for the Pliocene sequence at Hole 653A (Shipboard Scientific Party, 1987), the strontium isotope plateau began at approximately $4.5 \mathrm{Ma}$. and continued until $2.4 \mathrm{Ma}$.

From the latest Pliocene throughout the Pleistocene, the ${ }^{87} \mathrm{Sr} /{ }^{86} \mathrm{Sr}$ ratio tends to increase. There is a steep increase in ${ }^{87} \mathrm{Sr} /{ }^{86} \mathrm{Sr}$ ratio between 109.30 and $96.90 \mathrm{mbsf}$, at the beginning of the MP16 zone. This increase occurred between 2.4 and 2.1 $\mathrm{Ma}$, based on the average sedimentation rate. $\mathrm{The}{ }^{87} \mathrm{Sr} /{ }^{86} \mathrm{Sr}$ ratio peaked just prior to the Pliocene/Pleistocene boundary, and afterward there is a decrease in the ratio which reaches a ${ }^{87} \mathrm{Sr} /$ 
${ }^{86} \mathrm{Sr}$ minimum at $71.60 \mathrm{mbsf}$ (early Pleistocene; within the Globorotalia cariacoensis and NN19 nannofossil zones). Upsection, the ratio again increases steadily until 33.80 mbsf at the NN19/ NN20 boundary in the late Pleistocene ( $G$. truncatulonoides excelsa zone). This point is followed by a small decrease and a final maximum value at 5.93 mbsf within the NN21 zone.

Biostratigraphic correlation between the basal Pliocene of Holes $653 \mathrm{~A}$ and -B is possible with the recognition of two biostratigraphic events at both holes: (1) the end of the Sphaeroidinellopsis spp. acme and (2) the first occurrence of Globorotalia margaritae, which denotes the MP11/MP12 boundary (Shipboard Scientific Party, 1987). Together the five strontium isotopic values for the lower $10 \mathrm{~m}$ of the Pliocene at both holes show large fluctuations around a mean value of $0.708956 \pm$ 0.000055 (Table 1). This is in contrast to the rather stable, isotopically less-enriched value for the remainder of the Pliocene, $0.708923 \pm 0.000022$. Interestingly, five samples from the lowermost $10 \mathrm{~m}$ of the Miocene/Pliocene boundary-Zanclean stratotype section at Capo Rossello, Sicily, have a mean value of $0.708995 \pm 0.000020$ (McKenzie et al., 1988), suggesting that the lowermost Pliocene sediments from Hole 653A and -B might be slightly older.

The wide fluctuations in the strontium isotopic values seen in the basal Pliocene may represent a real phenomenon associated with unstable oceanographic conditions, and not be simply the result of analytical or sampling error. Interpretations of high-resolution, bio- and chemostratigraphy for the lowermost Pliocene (MP11 and basal MP12 zones) sediments cored at Holes $652 \mathrm{~A}, 653 \mathrm{~B}$, and 654A (McKenzie and Sprovieri, this volume) suggest strongly that during this period the Tyrrhenian Sea was in-filling and the water mass was not always a single, homogeneous body throughout the Sphaeroidinellopsis acme interval. Also, a catastrophic influx of cold, deep Atlantic water probably occurred coincident with the end of the acme. The appearance of the benthonic foraminifera Uvigerina pygmea at Hole $653 \mathrm{~A}$ at the end of the acme and its continued presence up to 206.7 mbsf are indicative of low oxygen, cold bottom waters, suggestive of sluggish circulation. Normal marine conditions, suggesting that a deep water connection with the Atlantic had been established, only begin to prevail stratigraphically above this depth. It is, thus, tentatively proposed that the mixing of different water masses with possibly different strontium-isotopic compositions during the in-filling of the Tyrrhenian Sea after the Messinian salinity crisis and the additional influx of cold, deep Atlantic water with a later tectonic break in the Gilbraltar sill could explain the wide fluctuations in the strontium-isotopic values. Müller et al. (this volume) likewise propose that complex hydrologic conditions existed in the Mediterranean during the Messinian salinity crisis and resulted in a large variability in the strontium-isotopic ratios of the evaporites. After about 4.7 Ma (above $204 \mathrm{mbsf}$ ), paleoceanographic conditions stabilized and the strontium-isotopic value remains relatively constant until near the Pliocene/Pleistocene boundary. This ${ }^{87} \mathrm{Sr} /{ }^{86} \mathrm{Sr}$ plateau probably reflects a worldwide lack of evolution or change in strontium isotopic values of seawater.

\section{DISCUSSION AND CONCLUSIONS}

The application of strontium isotopes to the study of stratigraphic problems is a relatively recent addition to the overall list of correlation methods. Aside from the analytical difficulties, two major problems currently exist with the application of the method as a correlation tool: (1) the effects of post-depositional alteration of the strontium-isotopic composition can be a significant factor and deprive the method of its stratigraphic potential and (2) the details in the strontium isotope-age curve are basically unknown and must be fully evaluated before it can be ap- plied to any specific period of interest (DePaolo, 1987). This study represents an attempt to develop a detailed strontium-isotope curve for the Pliocene-Pleistocene using deep-sea sediments from the Tyrrhenian Sea that are close to the stratotype localities in Italy. Unfortunately, the poor quality of the paleomagnetic signal at ODP Site 653, the proposed "deep-sea type section" for the Mediterranean Pliocene-Pleistocene, deprives this sequence of direct magnetostratigraphic ages; however biostratigraphic correlations to other sequences remain possible.

In general, the shape of the strontium isotope-depth curve for Hole $653 \mathrm{~A}$ resembles the less detailed, late Neogene part of the strontium isotope-age curve of DePaolo (1986), which contains an episode of stable values from 4 to $2.5 \mathrm{Ma}$ (NN14NN16). The plateau of the Hole 653A curve begins earlier at 4.5 $\mathrm{Ma}$ (NN13) and continues until $2.4 \mathrm{Ma}$ (NN16) Also, it is shifted toward slightly lower values, possibly due to differences in laboratory calibrations or sampling density. In any case, the apparent lack of change in the seawater ratio between 4.5 and 2.4 Ma eliminates strontium-isotope stratigraphy as a useful high-resolution stratigraphic method for this portion of geologic time. On the other hand, the greater resolution for Hole $653 \mathrm{~A}$ reveals that there is more structure in the latest Neogene curve than previously recognized.

A detailed study concentrating solely on late Neogene, openocean sediments from DSDP sites (Hodell et al., 1989) indicates that an accelerated increase in the ${ }^{87} \mathrm{Sr} /{ }^{86} \mathrm{Sr}$ ratio of seawater occurred between 5.5 and $4.5 \mathrm{Ma}$, followed by a nearly zero rate of change between 4.5 and $2.5 \mathrm{Ma}$. Another steep increase apparently began in the late Pliocene between 2.5 and $2.4 \mathrm{Ma}$. The data from Hole $653 \mathrm{~A}$ are consistent with these high-resolution results from open-ocean sediments. In particular, the observation that the zero-change interval occurs between 4.5 and 2.5 Ma matches well with the Hole 653A curve.

Further, the Hole 653A curve includes at least two periods of more or less rapid increase in ${ }^{87} \mathrm{Sr} /{ }^{86} \mathrm{Sr}$ in the late Pliocene-Pleistocene, centering around 2.4-2.0 Ma and from about 1.3 to 0.1 $\mathrm{Ma}$ (or to the top of the measured section). These two increases are separated by an interval where the ${ }^{87} \mathrm{Sr} /{ }^{86} \mathrm{Sr}$ ratio apparently was decreasing. The significance of these accelerated increases and decreases in ${ }^{87} \mathrm{Sr} /{ }^{86} \mathrm{Sr}$ is not fully understood. The late Pliocene-Pleistocene is recognized as a period of extreme climatic change with frequent glacial-interglacial fluctuations related to Northern Hemisphere cooling and warming. Of possible importance to this study is the notable and abrupt onset of glacial-interglacial fluctuations beginning at $2.37 \mathrm{Ma}$ and continuing up to the present, as interpreted from the oxygen isotope record (Shackleton et al, 1984). In a study of $\delta^{18} \mathrm{O}$ stratigraphy of planktonic foraminifers from Hole 653A, Grazzini et al. (this volume) recognized large positive excursions in the following time intervals: between 3.1 and $2.5 \mathrm{Ma}$, at 2.25 and $2.15 \mathrm{Ma}$, between 1.55 and $1.3 \mathrm{Ma}$, at 0.9 and $0.8 \mathrm{Ma}$, and near $0.34 \mathrm{Ma}$. These events can be interpreted as indicators of global cooling or eustatic sea level fall.

DePaolo (1986) has suggested that periods of rapid increase in the ${ }^{87} \mathrm{Sr} /{ }^{86} \mathrm{Sr}$ ratio of seawater follow major marine regressions. Testing this relationship at Hole 653A suggests that there may be a correspondence between glacial-interglacial events and the strontium isotopic curve. The rapid increases in the strontium isotopic curve between 2.4 and $2.0 \mathrm{Ma}$ and between 1.3 and $0.1 \mathrm{Ma}$ do apparently follow some of the positive oxygen isotopic events of Grazzini et al. (this volume). Obviously, these correlations remain very tentative, but more detailed strontiumisotope stratigraphy on sequences with good magneto- and biostratigraphic control, as well as oxygen-isotope data, is required to determine the relationship between regression-transgression cycles and the strontium-isotope composition of the oceans. 


\section{ACKNOWLEDGMENTS}

We would like to acknowledge R. Shuster for his generous assistance with the mass spectrometry. This research was partially supported by USSAC Grant 86032118 to J. A. McKenzie.

\section{REFERENCES}

Burke, W. H., Denison, R. E., Hetherington, E. A., Koepnick, R. B., Nelson, H. F., and Otto, J. B., 1982. Variation of seawater ${ }^{87} \mathrm{Sr} /{ }^{86} \mathrm{Sr}$ throughout Phanerozoic time. Geology, 10:516-519.

Capo, R. C., and DePaolo, D. J., 1987. Sr isotope variation in seawater associated with late Pleistocene glacial cycles. EOS Transactions, $A G U, 68: 448-449$.

DePaolo, D. J., 1986. Detailed record of the Neogene Sr isotopic evolution of seawater from DSDP Site 590B. Geology, 14:103-106.

, 1987. Correlating rock with strontium isotopes. Geotimes, 32:16-18.

DePaolo, D. J., and Ingram, B. L., 1985. High-resolution stratigraphy with strontium isotopes. Science, 227:938-941.

Elderfield, H., 1986. Strontium isotope stratigraphy. Palaeogeogr., Palaeoclimatol., Palaeoecol., 57:71-90.

Hess, J., Bender, M. L., and Schilling, J. G., 1986. Seawater ${ }^{87} \mathrm{Sr} /{ }^{86} \mathrm{Sr}$ evolution from Cretaceous to present-Applications to paleoceanography. Science, 231:979-984.
Hodell, D. A., Mueller, P. A., McKenzie, J. A., and Mead, G. A., 1989. Strontium isotope stratigraphy and geochemistry of the late Neogene ocean (9 to $2 \mathrm{Ma}$ ). Earth Planet. Sci. Lett., 92:165-178.

Koepnick, R. B., Burke, W. H., Denison, R. E., Hetherington, E. A. Nelson, H. F., Otto, J. B., and Waite, L. E., 1985. Construction of the seawater ${ }^{87} \mathrm{Sr} /{ }^{86} \mathrm{Sr}$ curve for the Cenozoic and Cretaceous: supporting data. Chem. Geol., 58:55-81.

McKenzie, J. A., Hodell, D. A., Mueller, P. A., and Mü1ler, D. W., 1988. Application of strontium isotopes to late Miocene-early Pliocene stratigraphy. Geology, 16:1022-1025.

Shackleton, N. J., Backman, J., Zimmerman, H., Kent, D. V., Hall, M. A., Roberts, D. G., Schnitker, D., Baldauf, J. G., Despairies, A., Homrighousen, R., Huddlestun, P., Keene, J. B., Kaltenback, A. J., Krumsiek, K.A.O., Morton, A. C., Murray, J. W., and WestbergSmith, J., 1984. Oxygen isotope calibration of the onset of ice-rafting and history of glaciation in the North Atlantic region. Nature, 307:620-623.

Shipboard Scientific Party, 1987. Site 653. In Kastens, K. A., Mascle, J., et al., Proc. ODP, Init. Repts., 107: College Station, TX (Ocean Drilling Program), 599-745.

Date of initial receipt: 21 March 1988

Date of acceptance: 17 January 1989

Ms 107B-160 